JURNAL PLANS

Penelitian Ilmu Manajemen \& Bisnis

ISSN: 1978-7057

\title{
ANALISIS KEBANGKRUTAN PERUSAHAAN DENGAN MODEL ALTMAN Z-SCORE PADA PERUSAHAAN MAKANAN DAN MINUMAN YANG TERDAFTAR DI BURSA EFEK INDONESIA PERIODE 2011-2014
}

\author{
Rio Evans B.M.S \\ Alumni Jurusan Manajemen Fakultas Ekonomi Universitas Negeri Medan \\ Cut Ermiati \\ Dosen Jurusan Manajemen Fakultas Ekonomi Universitas Negeri Medan
}

\begin{abstract}
This study examines the analysis of bankruptcy which uses a model Altman ZScore 1983 once studied the effect of variable ratio of Working Capital to Total Assets (X1), Retained Earnings to Total Assets (X2), Earnings Before Interest and Tax to Total Assets (X3), Book Value of Equity to Book Value of Total Debt (X4), and Sales to Total Assets (X5) against bankruptcy for companies that went bankrupt or for companies that are not bankrupt by the number of samples (purposive sampling as a sampling technique ) as many as 15 companies. The purpose of this study is to analyze the financial ratios Altman model to explain the company's financial condition foods and beverages as a first step in anticipation of bankruptcy. The analysis method in this research is to perform calculations using the Altman Z-Score Revised (1983) and multinomial logit analysis. Testing is done with the first models prerequisite analysis, testing normality with the overall result is a variable based test One Sample Kolmogorov-Smirnov test indicated that the model in an abnormal position with evidence of significant data $\alpha>0.05$. Second, the test results with the results multikolinieritas with VIF $<10$ and the tolerance level of $>0.1$ indicates that our model is free from the problems of multicollinearity. This is consistent with the assumption multinomial logit analysis that does not require the classical assumption that multinomial logit analysis can proceed. The results of this study are the calculations that have been done, that there are 10 companies in the category of Grey Area and 5 companies in the category is not bankrupt. Seen as a whole has a classification of $95 \%$, while the remaining 5\% indicates that bankruptcy is explained by other variables other than those examined in this study In this study the variable ratio of Book Value of Equity to Book Value of Total Debt and Sales to Total Assets have influence significantly to the bankruptcy analysis. So that this research model is Z-Score $=\operatorname{Ln}(P 1 / P 0)=-149.589+117,603 B V E B V D+33,029 S T A$ and $Z$-Score $=\operatorname{Ln}(P 2 / P 0)=$ $-117.301+111,623 B V E B V D+21,657 S T A$
\end{abstract}

Keywords: Bankruptcy, Multinomial Logit Analysis, Financial Ratios Altman Z-Score Model Of Revision.

\section{PENDAHULUAN}

Perekonomian Indonesia sebagian besar didukung oleh sektor manufaktur karena perusahaan manufaktur merupakan penopang utama perkembangan industri di sebuah negara. Perusahaan manufaktur yang tidak mampu mempertahankan kemampuan perusahaannya akan mengalami masalah keuangan yang biasanya ditandai dengan mengalami kerugian.

Pada tahun 2012, berdasarkan riset yang dilaporkan oleh UNIDO (Organisasi Pengembangan Industri Dunia), pertumbuhan industri manufaktur pada kuartal III tahun 2012 hanya sebesar 0,2 \%. Banyak 
ISSN: 1978-7057

sub sektor manufaktur yang mengalami pertumbuhan negatif dampak dari krisis ekonomi yang melanda di tahun 2012. Kondisi ini tak lain juga berimbas pada sub sektor konsumsi yakni perusahaan makanan dan minuman. Dalam fenomenanya, ketika sub sektor dalam sektor manufaktur terus mengalami penurunan negatif, tetapi sub sektor makanan dan minuman tidak menyentuh angka negatif walaupun juga mengalami penurunan yakni turun hanya $1 \%$. Sub sektor industri makanan dan minuman menjadi andalah di sektor manufaktur non migas di saat sub sektor lainnya berada di angka negatif. Dan mengalami pertumbuhan kembali sekitar 5-7 persen pada kuartal II 2012.

Penulis melakukan penelitian pada perusahaan manufaktur yang bergerak di bidang produksi makanan dan minuman. Sektor makanan dan minumana merupakan salah satu sektor yang paling dekat dengan masyarakat dan merupakan salah satu sektor usaha yang akan terus mengalami pertumbuhan. Seiring dengan meningkatnya pertumbuhan jumlah penduduk di Indonesia, permintaan konsumen akan makanan dan minuman ini akan terus meningkat.

Peningkatan pertumbuhan sektor makanan dan minuman akan meningkatkan persaingan. Perusahaan harus mengambil suatu kebijakan untuk meningkatkan volume penjualan dan kebijakan lainnya untuk mempertahankan kelangsungan operasi perusahaan. Berikut disajikan grafik penjualan dan laba bersih perusahaan makanan dan minuman yang terdaftar di Bursa Efek Indonesia

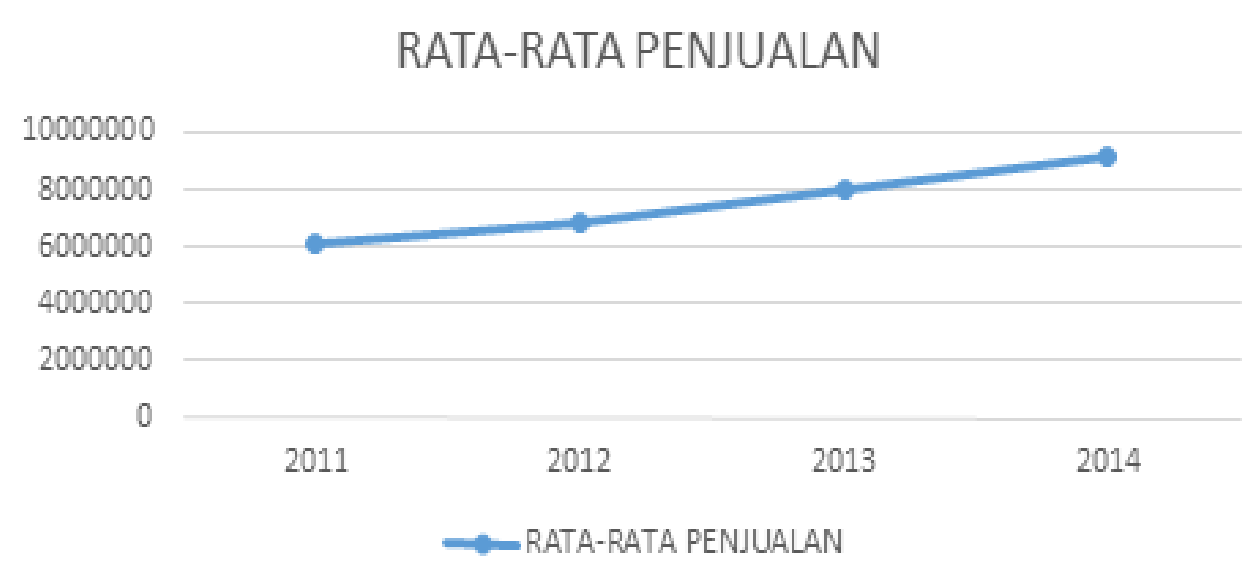

Sumber: Bursa Efek Indonesia (Data Diolah)

Gambar 1. Rata-rata Penjualan Perusahaan Makanan dan Minuman Terdaftar di BEI Tahun 2011-2014

Dari Gambar diatas terlihat bahwa peningkatan penjualan adalah bukti dari peningkatan pertumbuhan sektor makanan dan minuman. 
ISSN: 1978-7057

\section{RATA-RATA LABA BERSIH}

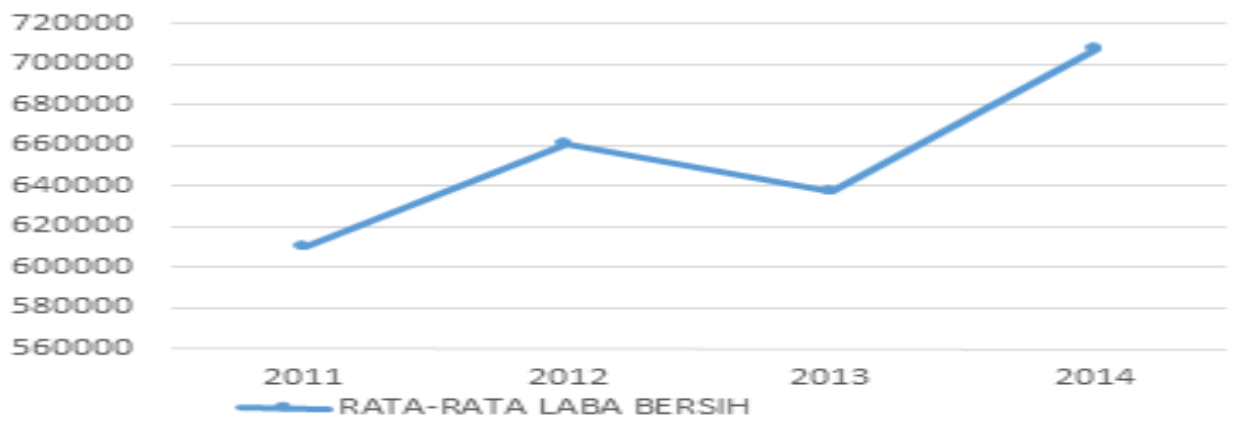

Sumber : Bursa Efek Indonesia

\section{Gambar 2. Rata-Rata Laba Bersih Perusahaan Makanan dan Minuman Terdaftar di BEI Tahun 2011-2014}

Namun, dari Gambar diatas peningkatan pertumbuhan sektor tidak berbanding lurus dengan laba bersih yang diterima perusahaan makanan dan minuman.Penjualan yang meningkat tidak diikuti dengan pertumbuhan laba bersih yang meningkat.Masih saja terjadi fluktuasi laba bersih yang berarti masih saja terdapat perusahaan yang mengalami penurunan laba atau laba negatif.Fenomena ini menjadi dasar penulis untuk melakukan penelitian potensi kebangkrutan yang dialami oleh perusahaan makanan dan minuman yang terdaftar di Bursa Efek Indonesia dilihat dari kondisi keuangannya.

Pihak manajemen perusahaan memiliki peran dalam pengendalian dan pengelolaan keuangan perusahaan.Termasuk ketika laba berfluktuatif tidak berbanding lurus dengan peningkatan penjualan perusahaan.Laba fluktuatif naik dan turun tajam juga bisa menjadi tanda kebangkrutan.Untuk itu perlunya analisis rasio keuangan sebagai langkah awal untuk mengantisipasi potensi kebangkrutan perusahaan guna menentukan rasio likuiditas, aktivitas, leverage, dan profitabilitas yang digunakan perusahaan tersebut sebagai dasar dalam penilaian kinerja.Salah satu analisis rasio keuangan adalah dengan menggunakan model prediksi kebangkrutan.

Terdapat beberapa model kebangkrutan yang telah dipakai dalam menganalisis kondisi keuangan perusahaan diantaranya model Altman, model Springate, Model Zimjewski, Model Ohlon dan Model Foster. Model Altman merupakan model prediksi kebangkrutan multivariate yang pertama kali diciptakan yang kemudian diikuti oleh model-model prediksi kebangkrutan lainnya. Model Altman memiliki tingkat akurasi tinggi pada awal penelitianya sebesar 95\% walaupun model lainnya memiliki keakuratan lebih tinggi setelah modelmodel lainnya itu diciptakan. Model Altman Z-Score memiliki kebaikan dibanding dengan model prediksi kebangkrutan lainnya.Diantaranya terlihat dari persamaannya, persamaan model Altman menghubungkan antara likuiditas, solvabilitas, dan profitabilitas perusahaan dengan kebangkrutan.Selain itu, kebaikan 
ISSN: 1978-7057

dari model ini dapat dipergunakan untuk seluruh perusahaan, baik perusahaan publik, pribadi, manufaktur, ataupun perusahaan jasa dalam berbagai ukuran. Model ZScore tidak rumit, karena model ini menggabungkan lima rasio keuangan yang diperoleh dari informasi laporan keuangan untuk menghasilkan pengukuran obyektif dari kesehatan keuangan perusahaan. Rasio-rasio keuangan yang yang digunakan dalam model Z-Score (Altman) antara lain: Working Capital to Total Asset, Retained Earning to Total Asset, Earning before Interest and Taxes to Total Asset, Market Value of Equity to Book Value of Liability, dan Sales to Total Asset.

Model kebangkrutan lainnya ada beberapa diantaranya lebih akurat, terutama untuk waktu yang lebih dari dua tahun.Namun, model tersebut lebih rumit dan lebih eksklusif.Walaupun model ini berasal dari Amerika, tetapi model ini dapat digunakan di negara-negara berkembang seperti Indonesia. Model Altman Z-Score dinilai cocok digunakan pada sektor industri manufaktur salah satunya adalah sub sektor makanan dan minuman yang terdaftar di Bursa Efek Indonesia.

\section{METODE PENELITIAN}

\section{Lokasi, Populasi, dan Sampel}

Penelitian ini dilakukan di Bursa Efek Indonesia melalui website resmi yaitu www.idx.co.id. Populasi dalam penelitian ini adalah semua perusahaan yang termasuk dalam perusahaan sektor makanan dan minuman yang terdaftar di Bursa Efek Indonesia (BEI) untuk periode 20112014 dengan jumlah perusahaan sebanyak 16 perusahaan. Penulis menggunakan metode Judgement Sampling dalam menentukan jumlah sampel penelitian.Berdasarkan pada karakteristik pengambilan sampel, maka jumlah sampel yang digunakan dalam penelitian ini adalah 15 perusahaan makanan dan minuman.

\section{Teknik Analisis Data}

Adapun teknik analisis data yang digunakan dalam penelitian ini adalah sebagai berikut :

1. Uji Asumsi Klasik

Perlu diadakan uji asumsi klasik dengan tujuan untuk memenuhi uji normalitas data apakah terbebas dari permasalahan normalitas data dan multikolinieritas.

2. Uji Multinomial Logistik

a. Menilai Model Fit

Langkah awal adalah menilai Overall Fit Model terhadap data. Beberapa test statistic diberikan untuk menilai hal ini. Hipotesis untuk menilai model fit adalah

H0 : Model yang dihipotesiskan fit dengan data.

H1 : Model yang dihipotesiskan tidak fit dengan data.

b. Nilai -2 Likelihood Ratio

Penilaian keseluruhan model regresi menggunakan nilai -2 Likelihood dimana jika terjadi penurunan dalam nilai -2 Likelihood pada blok kedua jika dibandingkan dengan blok pertama, maka dapat disimpulkan bahwa model regresi menjadi lebih baik. (Ghazali, 2005).

c. Koefisien Goodness of Fit Tes Goodness of fit menunjukkan apakah model cocok dengan data. Ada dua tes goodness of fit, yaitu 
ISSN: 1978-7057

Pearson dan Dviance. Nilai signifikan kedua tes ini lebih besar dari $\alpha=0,05$, hal ini menunjukkan model cocok dengan data (Cornelius Trihendardi,2007).

Tes ini digunakan untuk menguji hipotesis nol bahwa data empiris cocok atau sesuai dengan model (tidak ada perbedaan antara model dengan data, sehingga model data dikatakan fit), jika koefisien goodness of fit sama atau kurang dari 0,05 maka hipotesis nol ditolak yang berarati ada perbedaan signifikan antara model dengan nilai observasinya, sehingga goodness of fit model tidak baik karena model tidak dapat memprediksi nilai observasinya. Jika nilai statistik Chi Square Hosmer and Lemeshow Goodness of Fit lebih besar dari 0,05 maka hipotesis nol tidak dapat ditolak dan berarti model mampu memprediksi nilai observasinya. (Ghazali,2005).

d. Koefisien Pseudo R-Square Nilai statistik R Square pada analisis multinomial logistik didekati dengan nilai Pseudo Rsquare : Cox and Snell, Nagelkerke dan McFadden. Nilai pada rentang 0-1. Semakin mendekati 1, maka semakin banyak variasi yang dapat dijelaskan oleh model (Cornelius Trihendardi, 2007). Koefisien Cox and Snell R Square merupakan ukuran yang mencoba meniru ukuran Koefisien R Square pada
Regresi Linear Berganda yang didasarkan pada teknik estimasi Likelihood dengan nilai maksimum $<1$, sehingga sulit diinterpretasikan. Nagelkerke R Square merupakan modifikasi dari koefisien Cox and Snell R Square untuk memastikan bahwa nilainya bervariasi dari $0-1$. Hal ini dilakukan dengan cara membagi nilai koefisien Cox and Snell R Square dengan nilai maksimumnya. Nilai koefisien Nagelkerke R Square diinterpretasikan seperti koefisien R Square pada Regresi Linear Berganda.

e. Ketepatan Prediksi Klasifikasi

Tabel klasifikasi digunakan untuk menghitung nilai estimasi yang benar (correct) dan data yang tidak benar (incorrect). Pada kolom merupakan dua nilai dari variabel dependen yaitu Tidak Bangkrut, Grey Area, dan Bangkrut. Sedangkan pada baris menunjukkan nilai observasi sesungguhnya yang sesuai dengan data actual pada model yang sempurna, maka semua kasus akan berada pada diagonal dengan tingkat peramalan $\quad 100 \%$ (Ghazali,2005). Model matematis dalam penelitian ini adalah sebagai berikut :

Ln $\mathrm{P}$ (Yi=bangkrut) / P (Yi = tidak bangkrut) $=\mathrm{a}+$ b1WCTA + b2RETA + b3EBITTA + b4BVEBVD + b4STA + e1.....(1)

Ln P (Yi=bangkrut) / P (Yi = tidak bangkrut) $=\mathrm{a}+$ 
JURNAL PLANS

Penelitian Ilmu Manajemen \& Bisnis

ISSN: 1978-7057

$$
\begin{aligned}
& \text { b1WCTA }+ \text { b2RETA }+ \\
& \text { b3EBITTA }+ \text { b4BVEBVD }+ \\
& \text { b4STA }+ \text { e1....(2) } \\
& \text { Model Regresi sebagai } \\
& \text { berikut: } \\
& \mathbf{Z j}=\mathbf{b j}_{\mathbf{1}}+\mathbf{b j}_{2} \mathbf{X}_{\mathbf{2}}+\ldots+ \\
& \text { bjnXn } \\
& \text { Keterangan: } \\
& \mathrm{J}=\text { Kelompok perusahaan } \\
& \text { yang mendapatkan } 3 \text { kategori } \\
& \text { kebangkrutan } \\
& \text { Status = Kategori tidak } \\
& \text { bangkrut (0), kategori grey } \\
& \text { area (1), dan kategori bangkrut } \\
& (2) \text { Rasio-rasio } \\
& X_{1} \ldots X n= \\
& \text { Keuangan }
\end{aligned}
$$

\section{HASIL PENELITIAN DAN}

\section{PEMBAHASAN}

\section{Hasil Penelitian}

Analisis Model Multinomial Logit

Model Multinomial Logit berguna untuk memodelkan kategori kebangkrutan.Pada kasus ini, yang menjadi variabel dependen adalah kebangkrutan.Kebangkrutan

\begin{tabular}{|c|c|c|c|}
\hline & & $\mathrm{N}$ & $\begin{array}{c}\text { Marginal } \\
\text { Percentage }\end{array}$ \\
\hline \multirow[t]{3}{*}{ KEBANGKRUTAN } & Tidak B angkrut & 21 & $35.0 \%$ \\
\hline & Grey Area & 38 & $63.3 \%$ \\
\hline & Bangkrut & 1 & $1.7 \%$ \\
\hline Valid & & 60 & $100.0 \%$ \\
\hline Missing & & 0 & \\
\hline Total & & 60 & \\
\hline Subpopulation & & $60^{\mathrm{a}}$ & \\
\hline
\end{tabular}

diklasifikasikan menjadi tiga kategori yaitu tidak bangkrut, grey area, dan bangkrut.Kombinasi kelima variabel yaitu WCTA, RETA, EBITTA, BVEBVD, dan STA menjadi variabel independen pada model yang mempengaruhi kebangkrutan.

Dalam penelitian ini jumlah data yang diproses sebanyak 60 atau $\mathrm{N}=60$. Untuk melihat kelengkapan data yang diproses dalam penelitian ini dan tidak adanya missing case (data yang hilang), maka akan ditunjukkan oleh tabel case processing summary berikut:
Case Processing Summary

Dari hasil output pada tabel Case Processing Summary diatas dapat dilihat bahwa tidak ada data yang hilang, terdapat 21 yang diberikan perusahaan Tidak Bangkrut, terdapat 38 dalam kategori Grey Area dan terdapat 1 dalam kategori Bangkrut.

\section{a. Menilai Model Fit}

Hasil uji Overall Model Fit dengan menggunakan SPSS ditunjukkan pada Tabel berikut:

Model Fitting Information

\begin{tabular}{|l|r|r|r|r|}
\hline \multirow{2}{*}{ Model } & \multicolumn{1}{|c|}{$\begin{array}{c}\text { Model Fitting } \\
\text { Criteria }\end{array}$} & \multicolumn{3}{|c|}{ Likelihood Ratio Tests } \\
\cline { 2 - 5 } & \multicolumn{1}{c|}{$\begin{array}{c}-2 \text { Log } \\
\text { Likelihood }\end{array}$} & Chi-Square & Df & \multicolumn{1}{c|}{ Sig. } \\
\hline Intercept Only & 86.995 & & & \\
Final & 14.506 & 72.489 & 10 & .000 \\
\hline
\end{tabular}

Dari Tabel diatas dapat dilihat bahwa angka -2 Likelihood pada model awal (intercept only) sebesar 86,995 dan angka -2 Likelihood pada Model final sebesar 14,506.Karena hasil ini menunjukkan adanya penurunan, maka dapat ditarik kesimpulan bahwa model ini menunjukkan model multinomial logit yang lebih baik dan dapat diputuskan bahwa dapat menggunakan model lengkap untuk melakukan analisis. 
JURNAL PLANS

Penelitian Ilmu Manajemen \& Bisnis

ISSN: 1978-7057

b. Goodness of Fit Test

Goodness-of-Fit
\begin{tabular}{|l|r|r|r|}
\hline & Chi-Square & \multicolumn{1}{c|}{ Df } & \multicolumn{1}{c|}{ Sig. } \\
\hline Pearson & 26.338 & 108 & 1.000 \\
Deviance & 14.506 & 108 & 1.000 \\
\hline
\end{tabular}

Hasil Output Chi Square sebesar 26,338 untuk koefisien Pearson dan 14,506 untuk koefisien Deviance signifikan pada 1 , oleh karena nilai ini berada di atas $\mathrm{a}=0,05$ maka model dapat dikatakan fit dan model dapat diterima.

\section{c. Pseudo R-Square Test \\ Pseudo R-Square}

\begin{tabular}{|l|r|}
\hline Cox and Snell & .701 \\
Nagelkerke & .916 \\
McFadden & .833 \\
\hline
\end{tabular}

Nilai Statistik R-Square $\left(\mathrm{R}^{2}\right)$ pada analisis multinomial logistik didekati dengan nilai Pseudo RSquare : Cox and Snell, Nagelkerke, dan McFadden. Nilai pada rentang 01, semakin mendekati 1 maka semakin banyak variasi yang dapat dijelaskan oleh model. Nilai Koefisien Cox and Snell sebesar 0,701, nilai Koefisien Nagelkerke pada tabel sebesar 0,916 yang berarti bahwa variabilitas variabel dependen yang dapat dijelaskan oleh variabilitas variabel independen sebesar 91,6\%.

\section{d. Uji Likelihood Ratio}

dengan menggunakan SPSS

ditunjukkan pada Tabel berikut:
Likelinood Ratio Tests

\begin{tabular}{|l|r|r|r|r|}
\hline \multirow{4}{*}{} & $\begin{array}{c}\text { Model Fitting } \\
\text { Criteria }\end{array}$ & \multicolumn{3}{|c|}{ Likelihood Ratio Tests } \\
\cline { 2 - 5 } & $\begin{array}{c}\text {-2 Log } \\
\text { Likelihood of } \\
\text { Effect }\end{array}$ & & & \\
\hline Reduced Model & Chi-Square & Df & \multicolumn{1}{c|}{ Sig. } \\
WCTA & 80.474 & 65.967 & 2 & .000 \\
RETA & 14.537 & .031 & 2 & .985 \\
EBITTA & 25.885 & 11.379 & 2 & .003 \\
BVEB VD & 28.686 & 14.180 & 2 & .001 \\
STA & 33.210 & 18.703 & 2 & .000 \\
\hline
\end{tabular}

The chi-square statistic is the difference in - $2 \log$-likelihoods between the final model and a reduced model. The reduced model is formed by omitting an effect from the final model. The null hypothesis is that all parameters of that effect are 0 .

Likelihood Ratio Test merupakan uji signifikansi model yang memperlihatkan kontribusi pengaruh setiap variabel independen atau variabel faktor terhadap model. Hasil output multinomial logit pada kolom Sig terlihat bahwa untuk variabel faktor RETA memiliki kontribusi signifikan terhadap model yaitu sebesar 0,003, untuk variabel EBITTA memiliki kontribusi signifikan sebesar 0,001, untuk variabel BVEBVD memiliki kontribusi signifikan sebesar 0,00 dan variabel STA juga memiliki kontribusi signifikan sebesar 0,00 . Variabel tersebut dikatakan signifikan karena variabel tersebut memiliki nilai Sig lebih kecil a $=0,05$. Sedangkan variabel WCTA tidak memiliki kontribusi signifikan terhadap model karena memiliki nilai Sig lebih besar dari $a=0,05$. Hal ini mengindikasikan bahwa hanya variabel RETA, EBITTA, BVDBVE, dan STA yang dapat digunakan sebagai variabel bebas (Independent) dalam model Multinomial Logit yang dibuat. 
ISSN: 1978-7057

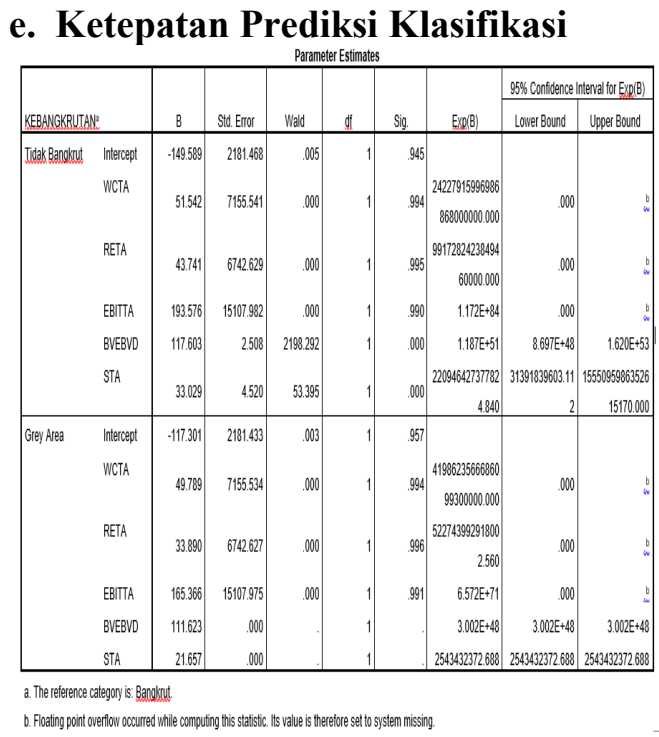

Hasil pengujian regresi multinomial logit pada tabel diatas, menunjukkan bahwa:

a. Variabel yang dapat digunakan untuk memprediksi probabilitas kebangkrutan yaitu antara kategori 0 dengan kategori 1 adalah variabel BVEBVD, dan STA dimana variabel tersebut memiliki nilai statistik signifikan pada tingkat $5 \%$.

b. Sedangkan variabel yang dapat digunakan untuk memprediksi kebangkrutan probabilitas kebangkrutan yaitu antara kategori 2 dan 1 yaitu variabel BVEBVD dan STA karena memiliki nilai Statistik Signifikan pada tingkat $5 \%$.

\section{f. Tabel Klasifikasi}

Classification

\begin{tabular}{|l|r|r|r|r|}
\hline \multirow{3}{*}{ Observed } & \multicolumn{4}{|c|}{ Predicted } \\
\cline { 2 - 5 } & Tidak Bangkrut & Grey Area & Bangkrut & Percent Correct \\
\hline Tidak B angkrut & 20 & 1 & 0 & $95.2 \%$ \\
Grey Area & 2 & 36 & 0 & $94.7 \%$ \\
B angkrut & 0 & 0 & 1 & $100.0 \%$ \\
Overall Percentage & $36.7 \%$ & $61.7 \%$ & $1.7 \%$ & $95.0 \%$ \\
\hline
\end{tabular}

$\begin{array}{ccr}\text { Dengan } & \text { daya } & \text { klasifikasi } \\ \text { (classification) } & \text { terlihat } & \text { secara }\end{array}$

keseluruhan memiliki daya klasifikasi sebesar 95\%, sedangkan sisanya sebesar 5\% menunjukkan bahwa kebangkrutan dijelaskan oleh variabel lain selain yang diteliti dalam penelitian ini misalnya masalah kebijakan manajemen, politik, dan lain-lain. Daya klasifikasi perusahaan kategori 0 sebesar $36,7 \%$, daya klasifikasi perusahaan kategori 1 sebesar $61,7 \%$ dan kategori 2 sebesar $1,7 \%$.

\section{Pembahasan Hasil Penelitian}

Hasil pengujian multinomial logit menunjukkan daya klasifikasi sebesar 95\%, hasil ini ditunjukkan dengan classification table pada model. Nilai koefisien Nagelkerke $R$ Square menjelaskan bahwa dalam model regresi ini kemampuan variabel WCTA, RETA, EBITTA, BVEBVD, dan STA sebesar 91,6\% dan sisanya $8,4 \%$ dijelaskan oleh variabel lain.

1. Working Capital to Total Asset Terhadap Analisis Kebangkrutan Perusahaan

Modal kerja yang digunakan perusahaan sebagai biaya operasi perusahaan yang diperoleh dari kelebihan aktiva lancar atas kewajiban lancar.Modal kerja ini dipakai untuk menghasilkan pendapatan jangka pendek.Semakin besar jumlah modal kerja bersih yang diperoleh perusahaan memungkinkan perusahaan dapat beroperasi secara ekonomis dan tidak mengalami potensi kebangkrutan. Penurunan modal kerja bersih yang dialami perusahaan ADES didorong oleh peningkatan kewajiban lancar yang tidak diiringi oleh peningkatan aktiva lancar. Peningkatan total aset pada perusahaan makanan dan minuman 
didorong oleh peningkatan jumlah aset tetap seperti penambahan mesin produksi, peningkatan kas perusahaan, peningkatan piutang tertagih dan peningkatan persediaan yang tidak hanya menyimpan barang yang tidak hanya pada gudang perusahaan. Penciptaan modal kerja bersih dari total aset yang meningkat akan menghasilkan modal kerja bersih yang meningkat juga. Maka tingkat likuiditas perusahaan akan semakin baik karena perusahaan mampu mengkonversikan sejumlah aset yang dimilikinya menjadi modal kerja. Hasil pengujian yang dilakukan menunjukkan bahwa rasio WCTA tidak berpengaruh signifikan terhadap analisis kebangkrutan perusahaan.Hal ini berarti penurunan atau peningkatan nilai WCTA perusahaan tidak memberikan pengaruh terhadap naik turunnya nilai Z-Score.

2. Retained Earning to Total Asset Terhadap Analisis Kebangkrutan Perusahaan

Secara keseluruhan tidak ada perusahaan yang masuk dalam kategori bangkrut.Tetapi pada tahun 2013, perusahaan ALTO termasuk ke dalam kondisi bangkrut. Hal ini disebabkan perusahaan mengalami penurunan penjualan, rasio RETA, EBITTA, BVEBVD, STA. Penurunan laba ditahan yang dialami perusahaan ALTO antara lain adanya penurunan laba laba bersih dari tahun sebelumnya. Selain untuk dividen, sebagian laba bersih ditujukan untuk dana cadangan. Sehingga sisanya yang akan digunakan untuk laba ditahan bernilai lebih kecil. Variabel RETA yang menunjukkan kemampuan perusahaan untuk menghasilkan laba ditahan dari total aktivanya merepresentasikan besarnya surplus yang dihasilkan perusahaan dari kegiatan operasionalnya serta pertumbuhan perusahaan kedepannya. Semakin tinggi nilai RETA mengakibatkan kecil kemungkinan perusahaan mengalami kebangkrutan.Namun, hasil pengujian yang dilakukan justru menunjukkan bahwa RETA tidak memberi pengaruh signifikan terhadap kebangkrutan.Berarti peningkatan atau penurunan nilai RETA tidak memberikan pengaruh signifikan terhadap penurunan atau kenaikan nilai Z-Score.

3. EBIT to Total Asset Terhadap Analisis Kebangkrutan Perusahaan Perusahaan yang berada dalam kategori grey area pada tahun 20112014 adalah ADES, AISA, ALTO, INDF, MYOR, ROTI, SKLT, dan STTP. Perusahaan mengalami penurunan EBIT yang membuat penurunan EBITTA. Penurunan nilai EBIT pada perusahaan ADES disebabkan oleh peningkatan beban penjualan akibat dari peningkatan kapasitas produksi perusahaan. Penurunan nilai EBIT juga dialami perusahaan AISA antara lain disebabkan penurunan pendapatan yang diperoleh dari Divisi Sawit. Pada perusahaan ALTO, penurunan EBIT didorong kuat oleh penurunan penjualan akibat pelemahan daya beli masyarakat yang secara otomatis juga menyebabkan merosotnya harga saham perusahaan.Penurunan marjin laba bersih yang dialami oleh perusahaan INDF adalah salah satu penyebab turunnya nilai EBIT perusahaan. Hal ini juga disebabkan oleh kerugian selisih kurs dan kenaikan beban operasional terutama beban gaji, upah, dan imbalan kerja karyawan, beban pengangkutan dan 
ISSN: 1978-7057

penanganan, serta promosi dan periklanan. Penurunan nilai EBIT yang dialami perusahaan MYOR didorong oleh peningkatan beban penjualan dan juga akibat kerugian selisih kurs yang dialami perusahaan.Penurunan yang juga dialami perusahaan ROTI disebabkan oleh beban bunga yang lebih tinggi dan biaya upah yang lebih besar, harga gas dan listrik yang meningkat, dan rupiah yang melemah sehingga perusahaan tidak dapat mempertahankan

marginnya.Penurunan juga terjadi pada perusahaan SKLT didorong adanya beban pajak kini serta kenaikan beban lain-lain. Dan perusahaan STTP yang juga mengalami penurunan nilai EBIT antara lain didorong oleh peningkatan beban pokok penjualan sehingga menekan turun laba kotor perusahaan. Semakin besar tingkat rasio maka tingkat produktivitas aset dalam menghasilkan pendapatan bagi perusahaan semakin meningkat.Hasil pengujian menunjukkan bahwa nilai EBITTA tidak memberikan pengaruh signifikan terhadap analisis kebangkrutan.Penurunan maupun kenaikan nilai tidak memberikan pengaruh signifikan terhadap kenaikan dan penurunan nilai ZScore.

4. Book Value of Equity to Book Value of Total Debt Terhadap Analisis Kebangkrutan

Perusahaan yang berada dalam kategori tidak bangkrut tahun 20112014 adalah CEKA, DLTA, ICBP, MLBI, PSDN, SKBM, dan ULTJ.Beberapa perusahaan tersebut berada dalam kondisi tidak bangkrut disebabkan kenaikan pada total equity.Pada perusahaan CEKA, dalam laporan keuangannya dikatakan bahwa peningkatan ekuitas disebabkan oleh peningkatan saldo laba yang belum ditentukan penggunaannya. Perusahaan ICBP yang juga mengalami kenaikan ekuitas antara lain disebabkan oleh perusahaan INDF yang menjadi induk perusahaan ICBP melakukan IPO ke bursa pada tahun 2011. Dari IPO ini didapatkan dana segar yang kemudian digunakan untuk ekspansi. Kenaikan modal diterbitkan dan disetor serta agio saham perusahaan SKBM adalah akibat dari saham baru yang diterbitkan dari program employee and management stock option Perseroan sebesar Rp 5.307.465.000.Perusahaan ULTJ uang juga mengalami kenaikan ekuitas disebabkan adanya peningkatan saldo laba yang sudah ditentukan penggunaannya dan saldo laba yang belum ditentukan penggunaannya.

Hasil pengujian yang menunjukkan bahwa variabel BVEBVD signifikan terhadap analisis kebangkrutan adalah sesuai dengan peningkatan ekuitas atau modal untuk memenuhi kewajiban-kewajiban perusahaan. Peningkatan atau penurunan rasio BVEBVD akan mempengaruhi nilai dari Z-Score.

5. Sales to Total Asset Terhadap Analisis Kebangkrutan Perusahaan

Peningkatan penjualan adalah bukti efisiensi manajemen perusahaan dalam mengelola asetnya untuk menghasilkan penjualan dan mendapatkan laba. Kenaikan penjualan bersih pada perusahaan CEKA didukung oleh aktivitas pengolahan Crude Palm Oil (CPO) dan Palm Kernel (PK) dan penjualannya di pasar domestic dan ekspor serta perusahaan mengurangi 
JURNAL PLANS

Penelitian Ilmu Manajemen \& Bisnis

ISSN: 1978-7057

banyak aktivitas jasa olah CPO. Kenaikan penjualan perusahaan DLTA disebabkan adanya kenaikan pangsa pasar pada tahun 2011 seiring ekspansi yang dilakukan perusahaan.Ekspansi yang dilakukan adalah dengan perluasan distributor ke sejumlah wilayah di Indonesia.Kenaikan penjualan pada perusahaan ICBP didorong adanya kenaikan harga jual rata-rata.Adapun divisi terbesar perseroan adalah mi instan, yang mengontribusi hingga $65 \%$ terhadap penjualan bersih perusahaan.Kenaikan penjualan perusahaan MLBI didorong oleh kenaikan penjualan yang sejalan dengan pertumbuhan jumlah turis asing yang datang pada akhir tahun di Indonesia yang memicu peningkatan penjualan bir di Indonesia.Kenaikan penjualan perusahaan PSDN didorong oleh peningkatan kapasitas produksi terutama kopi dan karet didukung dengan penambahan mesin pengolahan yang bertujuan untuk meningkatkan produksi. Kenaikan yang juga terjadi pada perusahaan SKBM antara lain disebabkan adanya usaha pengembangan produk-produk olahan perusahaan, baik di pasar local maupun internasional. Dan kenaikan penjualan yang terjadi pada perusahaan ULTJ antara lain didorong oleh peningkatan pasokan ke pasar modern.

Peningkatan penjualan yang terjadi di sejumlah perusahaan akan mempengaruhi laba yang dihasilkan. Semakin besar jumlah penjualan menunjukkan efisiensi manajemen perusahaan dalam mengelola aktivanya maka laba semakin besar. Peningkatan rasio ini akan memperkecil kemungkinan perusahaan menghadapi kebangkrutan.

Likelihood ratio test yaitu uji secara parsial menunjukkan bahwa variabel BVEBVD, STA yang memiliki pengaruh signifikan pada tingkat 5\%. Sehingga variabel yang dapat digunakan untuk mengklasifikasi kategori 0 dengan kategori 1 dan kategori 2 adalah variabel earning before interest and taxes to total assets dan sales to total assets.

Berdasarkan nilai koefisien B pada tabel parameter estimates, maka diperoleh persamaan untuk menginterprestasikan analisis multinomial logit yaitu :

$$
\begin{gathered}
\text { Z-Score }=\text { Ln }(\mathrm{P} 1 / \mathrm{P} 0)= \\
149,589 \\
\text { 117,603BVEBVD } \\
\text { 33,029STA }
\end{gathered}
$$

Pada persamaan tersebut jika variabel-variabel independen dianggap nol, maka akan diperoleh persamaan sebagai berikut :

$$
\begin{aligned}
\operatorname{Ln}(\mathrm{P} 0 / \mathrm{P} 2) & =-149,589 \\
(\mathrm{P} 0 / \mathrm{P} 2) & =\operatorname{Exp}(-149,589) \\
\mathrm{P} 0 / \mathrm{P} 2 & =0
\end{aligned}
$$

Hal ini berarti probabilitas variabel BVEBVD dan STA untuk memprediksi perusahaan berada dalam kategori bangkrut adalah 0 kali probabilitas untuk memprediksi perusahaan yang tidak berada dalam kategori bangkrut. Dengan kata lain bahwa variabel BVEBVD dan STA memiliki kemampuan yang sama untuk memprediksi perusahaan yang mendapat kategori kategori bangkrut dengan perusahaan yang mendapat kategori tidak bangkrut.

Koefisien BVEBVD sebesar 117,603 yang berarti bahwa variabel rasio keuangan BVEBVD memiliki hubungan positif dan secara statistic 
ISSN: 1978-7057

signifikan dengan probabilitas perusahaan pada kelompok 2 dan 3 , artinya semakin tinggi earning before interest and taxes to total asset yang dimiliki perusahaan, maka semakin tinggi pula peluang untuk mendapatkan kategori tidak bangkrut.

Koefisien STA sebesar 33,029

yang berarti bahwa variabel sales to total asset mempunyai hubungan positif dan secara statistic dengan probabilitas perusahaan pada kelompok 2 dan 3, artinya semakin tinggi tingkat penjualan per total aset semakin tinggi pula probabilitas perusahaan mendapatkan kategori tidak bangkrut.

Sementara variabel yang dapat digunakan untuk mengklasifikasikan kelompok 2 dan kelompok 3 adalah juga variabel BVEBVD dan STA yang secara statistk signifikan pada tingkat 0,05 atau $5 \%$.

Berdasarkan koefisien (B) pada tabel parameter estimates maka diperoleh persamaan untuk menginterpretasikan analisis multinomial logit yaitu:

Z-Score $=\operatorname{Ln}(\mathrm{P} 2 / \mathrm{P} 0)=$
$117,301+111,623 \mathrm{BVEBVD}$
$21,657 \mathrm{STA}$

Pada persamaan tersebut jika variabel-variabel independen dianggap nol, maka akan diperoleh persamaan sebagai berikut :

$$
\begin{aligned}
\operatorname{Ln}(\mathrm{P} 2 / \mathrm{P} 0) & =-117,301 \\
(\mathrm{P} 2 / \mathrm{P} 0) & =\operatorname{Exp}(-117,301) \\
(\mathrm{P} 2 / \mathrm{P} 0) & =0
\end{aligned}
$$

Angka tersebut berarti bahwa probabilitas variabel BVEBVD dan STA untuk memprediksi perusahaan akan mendapatkan kategori bangkrut dengan probabilitas 0 untuk memprediksi perusahaan akan mendapatkan kategori tidak bangkrut. Dengan kata lain bahwa earning before interest and taxes to total asset dan sales to total asset memiliki peluang atau kemampuan yang sama untuk memprediksi perusahaan mendapatkan kategori bangkrut dengan bahasa penjelas dibandingkan untuk memprediksi perusahaan yang mendapatkan kategori bangkrut.

Nilai koefisien BVEBVD sebesar 111,623 yang berarti bahwa variabel BVEBVD memiliki hubungan positif dan secara statistik signifikan dengan probabilitas perusahaan pada kelompok 3, artinya semakin tinggi tingkat rasio total modal per total kewajiban maka semakin tinggi pula probabilitas perusahaan untuk mendapatkan kategori tidak bangkrut.

Koefisien STA sebesar 21,657 yang berarti bahwa variabel sales to total asset mempunyai hubungan positif dan secara statistik dengan probabilitas perusahaan pada kelompok 3, artinya semakin tinggi tingkat penjualan per total aset semakin tinggi pula probabilitas perusahaan mendapatkan kategori tidak bangkrut.Hal ini sesuai dengan penelitian yang dilakukan Sarwani \& Rasidah (2008) bahwa faktor yang mempengaruhi tinggi rendahnya nilai $\mathrm{Z}$ adalah penjualan, dan nilai buku hutang yang diperoleh perusahaan.

\section{PENUTUP}

Dari hasil pembahasan pada penelitian ini dapat ditarik kesimpulan sebagai berikut :

1. Model penelitian analisis kebangkrutan Model Altman ZScore dapat dituliskan dalam persamaan:

$\mathrm{Z}-\mathrm{Score}=\mathrm{Ln}(\mathrm{P} 1 / \mathrm{P} 0)=-149,589+$ $117,603 \mathrm{BVEBVD}+33,029 \mathrm{STA}$ dan 
ISSN: 1978-7057

$\mathrm{Z}$-Score $=\operatorname{Ln}(\mathrm{P} 2 / \mathrm{P} 0)=-117,301+$ 111,623BVEBVD + 21,657STA

2. Rasio-rasio keuangan model Altman Z-Score dapat memprediksi dan menjelaskan kebangkrutan sebanyak 95\%. Diantaranya peningkatan dan penurunan modal kerja (WCTA) didorong peningkatan kewajiban lancar atas aktiva lancar, peningkatan dan penurunan laba ditahan (RETA) didorong penurunan laba bersih akibat penurunan penjualan, peningkatan dan penurunan nilai EBIT (EBIITA) didorong oleh peningkatan beban penjualan., peningkatan dan penurunan total ekuitas (BVEBVD) didorong oleh peningkatan saldo laba yang dicadangkan dan stock split yang dilakukan perusahaan. Dan peningkatan dan penurunan penjualan (STA) didorong oleh kenaikan pangsa pasar dan peningkatan kapasitas produksi.

3. Rasio Aktivitas memiliki pengaruh signifikan dalam analisis kebangkrutan yang diproksikan oleh variabel BVEBVD. Rasio aktivitas lainnya juga memiliki pengaruh signifikan dalam memprediksi kebangkrutan yaitu diproksikan dengan variabel STA.

\section{DAFTAR PUSTAKA}

Altman, E.L. 1968. Financial Ratio, Discrminant Analysis, and The Prediction of Corporate Bankcrupcty. The Jurnal of Finance.September (2005).

Alwi, Syafruddin. 1994. Alat-alat Analisis dalam Pembelanjaan. Edisi Keempat. Yogyakarta : Lembaga Penerbit Andi Offset.
Bernstein dalam Harahap, Sofyan Syafri. 2002. Analisis Kritis Atas Laporan Keuangan. Jakarta: PT Grafindo Persada.

Brahmana, Rayenda, K. Identifying Finacial Distress Condition In Indonesia Manufacture Industry, 2005.

Cornelius Trihendardi. 2007. Langkah Mudah Menguasai Analisis Statistik Menggunakan SPSS 15.Yogyakarta: Penerbit Andi.

Fahmi, Irfan. 2011. Analisis Laporan Keuangan. Bandung : Alfabeta.

Fakhrurozie. 2007. Analisis Pengaruh Kebangkrutan Bank Dengan Metode Altman Z-Score Terhadap Harga Saham Perusahaan Perbankan Di Bursa Efek Jakarta. Skripsi Universitas Negeri Semarang, Semarang.

Fitriyah, Ida. 2013. Pengaruh Rasio Keuangan Terhadap Financial Distress Pada Perusahaan Properti dan Real Estate. Jurnal Manajemen Universitas Negeri Surabaya.

Ghozali, Imam. 2005. Aplikasi Analisis Multivariat dengan Program SPSS. Semarang: Penerbit Universitas Diponegoro.

Gitman, Lawrence J dan Chad J. Zutter. 2012. Principles of Managerial Finance. $13^{\text {th }}$ Edition. Global Edition : Pearson Eduaction Limited.

Hadi, S dan Anggraeni.A. 2008. Pemilihan Prediktor Delisting Terbaik (Perbandingan Antara The Zmijewski Model, The Altman Model, dan The Springate Model). FE UII. 
ISSN: 1978-7057

Ikatan Akuntan Indonesia. 2009. Standar Akuntansi Keuangan. Salemba Empat. Jakarta.

James C. van Horne dalam Kasmir. 2010. Pengantar Manajemen Keuangan. Jakarta: Kencana.

John J.W.,K.R Subramanyan Dan Robert F. Hasley. 2005. Analisa Laporan Keuangan. Edisi Kedelapan. Buku 2.Jakarta : Salemba Empat.

Jumingan. 2008. Analisis Laporan Keuangan. Jakarta : Bumi Aksara.

Kasmir. 2010. Pengantar Manajemen Keuangan. Jakarta : Kencana.

Lesmana, Rico. 2003. Pedoman Menilai Kinerja untuk Perusahaan Tbk, Yayasan, BUMN, BUMD, dan Organisasi Lainnya. Edisi Pertama. Jakarta : Elex Media Komputindo.

Martin dalam Nugraheni. 2005. Analisis Ketepatan Prediksi Potensi Kebangkrutan Melalui Altman Z-Score dan Hubungannya Dengan Harga Saham Pada Perusahaan Perbankan Yang Listing Di Bursa Efek Jakarta. Jurusan Ekonomi. Program Studi Akuntansi. Fakultas Ilmu Sosial Universitas Negeri Semarang. $95 \mathrm{~h}$.

Mabruroh. 2004. Manfaat dan Pengaruh Rasio Rasio Keuangan Dalam Analisis Kinerja Keuangan Perbankan. Benefit, Jurnal_Volume 8 Nomor 1.

Nachrowi, Nachrowi Djalal. 2005. Penggunaan Teknik Ekonometri. Jakarta: PT Raja Grafindo Persada.
Ramadhani, Ayu Suci dan Niki Lukviarman. 2009. Perbandingan Analisis Prediksi Kebangkrutan Menggunakan Model Altman Pertama, Altman Revisi, dan Altman Modifikasi dengan Ukuran dan Umur Perusahaan Sebagai Variabel Penjelas (Studi pada Perusahaan Manufaktur yang Terdaftar di Bursa Efek Indonesia). Jurnal Siasat Bisnis, Volume 13, Nomor 1, pp.15-28.

Retno, Tri Setyowati. 2008. Analisis Rasio Keuangan untuk Menilai Kinerja Perusahaan Goods Consumer. Jurnal Ekonomi Akuntansi Universitas Muhammadiyah, Surakarta.

Santoso, Singgih. 2002. Buku Latihan SPSS Statistik Multivariat.Jakarta :PT Elex Media Komputindo.

Sarwani dan Rasidah. 2008. Analisis Diskriminan Model Altman ZScore dalam Mengukur Kinerja Keuangan Untuk Memprediksi Kebangkrutan Pada Industri Kayu Yang Terdaftar Di Bursa Efek Jakarta. Jurnal Ekonomi Pembangunan Manajemen dan Akuntansi, Volume 7, Nomor 2, pp. 200-230.

Sutrisno.2009. Manajemen Keuangan Teori, Konsep dan Aplikasi. Yogyakarta: Ekonisis.

Syafri Harahap, Sofyan. 2013. Analisis Kritis Atas Laporan Keuangan. Raja Grafindo Persada: Yogyakarta.

Van Horne, James dan Wachowicz, John. 2005. Prinsip Prinsip Manajemen Keuangan. Jakarta : Salemba Empat. 